\title{
The Mathematician, the Monk, and the Militant: Reflections on the Role of Criminal Law Theory
}

\author{
Stephen J. Schulhofer $\dagger$
}

\section{INTRODUCTION}

Professor George Fletcher's very interesting contribution to this Symposium provides a marvelous overview of the field of criminal law theory. ${ }^{1}$ Packed into his brief Essay are dozens of thought-provoking questions and many fresh and controversial claims.

My Response will undertake three tasks. I will first try to summarize his central claims. Then I will offer a brief critique. Finally, I will pick up on Professor Fletcher's challenge to define the functions of criminal law theory; I will present, as an alternative to his own answer, four competing and inconsistent conceptions of what the functions of criminal law theory might be. The first three conceptions are telegraphed, albeit somewhat obscurely, by my title. The final conception, the best, if you will, can be named only by reference to the man who embodies its virtues: Sandy Kadish, former Dean at Boalt Hall and reigning Dean, now as always, of the community of criminal law scholars. Dean Kadish is not only a most worthy heir to Herbert Wechsler, but he has filled a broader and deeper role, aiming not only to rationalize the criminal law but to connect it to the moral underpinnings that are crucial for its legitimacy and force. This Response honors, specifically, Professor Fletcher's provocative Essay, and more generally, the incomparable body of teaching, mentorship, and scholarly writing that constitutes Dean Kadish's breathtaking oeuvre.

Copyright $\odot 2000$ California Law Review, Inc. California Law Review, Incorporated (CLR) is a California nonprofit corporation. CLR and the authors are solely responsible for the content of their publications.

$\dagger \quad$ Julius Kreeger Professor of Law and Criminology and Director of the Center for Studies in Criminal Justice, University of Chicago.

1. See George P. Fletcher, The Nature and Function of Criminal Law Theory, 88 CALlF. L. Rev. 687 (2000). 


\section{PROFESSOR FLETCHER's ClAIMS}

Professor Fletcher's first main point is that law and philosophy are different kinds of inquiry, with law being inherently parochial and bound by precedent. ${ }^{2}$ But Fletcher qualifies this claim in two revealing ways. First, he says, when precedent is solid and consistent, it acquires a kind of force that becomes binding for normative philosophy. In other words, practice trumps theory. Harm, for example, matters; because practice on the issue is so uniform, the harm that actually occurs deservedly has significance for punishinent (so Fletcher argues) that is independent of the harm intended or risked. But second, Fletcher says, sometines practice does not trump theory, even when the practice is quite solid and consistent. ${ }^{4}$ For example, the felony-murder rule does not acquire normative force, despite its pervasive acceptance in American law.

Fletcher is aware, of course, of the tension between these two qualifications; therein, he says, lies the challenge for theorists. ${ }^{5}$ We may add that the tension is especially puzzling because the solid practice to which Fletcher is prepared to attribute normative force ("harm matters") entails precisely the same principle as the solid practice that he rejects ("felonies are punished as murder, regardless of intent, when death results"). We may wonder, then, whether practice really does trump theory, and if so, whether it acquires normative force only when it accords with the observer's own intuitions.

Fletcher's second major claim is that political and moral philosophy differ, and that the latter takes second place to the former. ${ }^{6}$ Political philosophy, he says, is the kind that is crucial for criminal law theory.

Third, Fletcher asserts that the function of theory is to explicate legal details, taking actual results in cases as given. ${ }^{8}$ The decisions are binding because legal actors themselves have felt bound. ${ }^{9}$

\section{II}

\section{SOME RESERVATIONS}

I am compelled to question all three of Fletcher's claims. First, practice should never trump theory. Practice unay give us pause, reason to reflect and to question our assumptions. But the normative force of practice depends on its grounding in principles that, on reflection, we notice and

2. See id. at Part I.A.

3. See id. at 692-693.

4. See id. at 693.

5. See id. at 693.

6. See id. at Part I.B.

7. See id. at 698-699.

8. See id. at Part II.

9. See id. at 702 . 
realize we can defend. Absent an ability to identify such principles, the practice itself carries no normative weight.

Second, political philosophy - the theory of the state-is for the most part unimportant for purposes of doing work in criminal law theory. Competing theories of the state rarely yield discrete, incompatible prescriptions for concrete cases. But divergent prescriptions can routinely be generated within the framework of any particular theory of the state. Good work in criminal law theory must suggest paths to resolving concrete problems that can be taken from one or several of the plausible political starting poimts. But there is rarely mileage to be gained, in terms of criminal law theory, from sorting out which is the appropriate theory of the state.

Finally, the function of theory is not (or not very importantly) to explicate patterns that emerge from the body of case law as it stands. Why not? Because law is a human institution, with all the complexities and instabilities that this characteristic implies. Criminal law outcomes are not merely patterns in the use of language and concepts. They are iron gates that slam shut on real people; they are keys that open doors and permit individuals to return (dangerous though they may be) to live among us. A theory of this social practice must justify its results by reference to normative principles that we can defend on reflection, not by reference to tradition or a pattern of decisions from times long past. ${ }^{10}$

A corollary of the preceding point is that there will rarely be solid, uniform patterns of decision on any difficult question that really matters. But what if, perchance, there were on some question a deep and persistent pattern, analogous to the deep structures that some philosophers believe they find in our language? If these deep structures exist in law, what is their moral force?

I rate their moral force as exactly zero.

Consider as an example the issue of sexual aggression. If anything is hard-wired in our brains or in our apparatus of instinct, judgment, and emotion, it is lust. Though the proposition is highly debatable, some argue that the male of our species may be hard-wired to desire a large number of sexual interactions. ${ }^{11}$ If so, what follows for moral judgment in cases where we see this instinct at work? Nothing at all. It is the distinctive office of morality to act as a brake on our impulses, however genuine or biologically driven they may be, to mold or at least check our deep, hard-wired instincts. Proving (if indeed it can be proved) that polyg amous lust is hardwired to our (male or female) cores may shed light on tactics that may be

10. For elaboration of these points, see Stephen J. Schulhofer, Book Review, 68 CALIF. L. REv. 181 (1980) (reviewing George P. Fletcher, Rethinking Criminal Law (1978)).

11. See, e.g., Owen D. Jones, Sex, Culture, and the Biology of Rape: Toward Explanation and Prevention, 87 CALIF. L. REv. 827 (1999). 
needed or effective, but it would shed no light whatever on the question of moral judgment.

Law is-and has been for more than 2000 years-not just a social institution but a socializing institution. Its task is to tame and change the deep structures when they produce or condone behavior that for sufficient reasons we come to understand, in our time, as socially noxious. Whatever the proper functions of theory may be, finding and celebrating patterns implicit in judicial decisions is not one of them.

III

\section{The FunCtIONS OF THEORY}

Thus far I have been negative and critical. Nonetheless, I agree with Professor Fletcher's larger poimt that it is important to identify and articulate what it is that we should be doing when we do criminal law theory. So I will attempt to take up his challenge and defend an affirmative conception of what criminal law theory should be.

I suggest that there are three prevalent conceptions of criminal law theory. First is the conception of theory as an intellectually satisfying, internally consistent enterprise, worthwhile for its own sake, roughly analogous to theorizing about chess, geometry, or the prime numbers. The criminal law theorist is the Mathematician of fault, generating an elaborate, logically coherent apparatus of doctrine from one or a few axioms ("penal liability must be proportionate to fault," for example). Like specialists in any other branch of mathematics, this kind of theorist finds satisfaction in the elegance and consistency of the entire structure. Real-world applications are neither sought nor considered; a charge of "irrelevancy" is supremely beside the point.

The second conception holds that theory can, and ideally should, have direct relevance to what is done in the real world but recognizes that the world as it stands is simply in no mood to hear or follow the dictates of sound theory. The theorist, as a result, must on no account water down his principles or permit his analysis to be tainted by opportunistic acquiescence in what contemporary politics considers acceptable. With public opinion currently dorminated by harsh, vindictive responses to crime, and short-sighted, unreflective demonization of criminal offenders, this type of theorist considers it far better to preserve the purity of criminal law doctrine and to work to elaborate its principles and implications, without stooping to practice the art of the possible. The point for this theorist is not that coherence and purity are all that count-consequences matter. But the theorist as Monk works to refine an important form of moral truth and to preserve it for use, in the hope that a time more receptive to its message will arrive. 
The third conception is intensely practical. It maintains that theory should serve the effort to enhance the justice and fairness of criminal law practices in our world today. The theorist might choose not to participate actively in litigation, perhaps because that activity is not to his temperament, but he hopes that his work will shape contemporary debates and influence those who do litigate, decide cases, and enact statutes. The theorist as Militant hopes to have impact, the sooner the better.

The image of the theorist as Militant is jarring because few committed theorists picture themselves plotting strategy, lobbying potential allies, or standing at the barricades, paving stone in hand. To self-identify as a theorist is consciously to reject roles of this sort; as a category, "militant theory" is a nonstarter, verging on the oxymoronic.

There is a fourth possibility, however. The fourth conception marries the temperament of the genuine theorist to the Militant's eye for practical effect. ${ }^{12}$ As a theorist, this scholar is careful and reflective, willing to follow truth wherever it may lead. But he also wants his work to contribute to clearer thinking and substantively better outcomes on the important controversies of the day. A theorist of this ilk can be identified by two features that define his work. He chooses to focus on issues of major practical sigmificance, and his mode of inquiry is fine-grained and concrete, attentive to the details that determine what will work, not just in a hypothetical universe, but here on earth, in messy, all-too-human imstitutions.

There is no readily accepted label that describes this fourth sort of theorist. But the term that comes most readily to mind is Kadishian. Sandy is most assuredly a theorist. By disposition tirelessly reflective, he is extremely careful, always willing to follow the implications of his own analysis, wherever they may lead. And, truth be told, there is a bit of the Monk or even the Mathematician in Sandy; witness his fine-spun hypotheticals concerning Lady Eldon, ${ }^{13}$ the driver on the narrow, precipitous nountain road, ${ }^{14}$ or the terrorist whose insane husband and eight-yearold son are firing a machine gun..$^{15}$

Sandy has been proud to serve as mentor and role model to a generation of theorists who have followed in these footsteps, elaborating on such

12. At the Symposium Meir Dan-Cohen suggested still another possibility: the theorist as Educator. The Educator would, presumably, aspire to foster among his students or among the public at large a capacity for clear thinking and intellectual discipline. Helping spread these requisites of good citizenship can be valuable, without regard to whether they promote the immediate success of any particular program.

13. See Sanford H. Kadish \& Stephen J. Schulhofer, Criminal law and Its Processes 633-40 (6th ed. 1995). The case, of course, is vintage Kadish; his junior collaborator cannot claim even partial authorship.

14. See id. at 965. Again, Kadish's junior collaborator cannot claim even partial authorship with respect to this case.

15. See SANFord H. Kadish, Blame ANd Punishment 122-23 (1987). Sandy himself describes this hypothetical as "farfetched." KADISH \& SCHULHOFER, supra note 13, at 879. 
hypotheticals and offering new ones of breathtaking creativity. We must remember that work in this genre, the work of the Monk and the Mathematician ("pure" theory, it is sometimes called), is only one strand in the fabric of work that has made the Kadish opus so distinctive and so important.

For large segments of his career, Sandy's scholarship has confronted both the practical nuts and bolts of criminal justice administration and the pressing political problems of his day. His article on the Supreme Court's role in setting standards of criminal procedure in the state courts ${ }^{16}$ is one of the most cited articles in the history of the Yale Law Journal ${ }^{7}$-and not by accident, for it engaged im a fresh and insightful way the problem that was the issue of constitutional law at the time. His work on discretion in the police and sentencing processes ${ }^{18}$ is one of the most thoughtful discussions of that intensely practical problem in the moral legitimacy of power, the problem that lies at the flashpoint where theoretical imperatives and realworld aspirations collide. His article ${ }^{19}$ and book $^{20}$ on the legitimacy of bending (and breaking) the rules, written with his brother Mort, is a rigorous theoretical study, but it is not just a scholar's enjoyment of a challenging intellectual puzzle. The problem that engaged the Kadish brothers, civil disobedience, was a pressing and intensely contentious political problem of the day, and their analysis of it proved influential in the judicial decision that now, almost three decades later, still governs the law's approach to jury nullification. ${ }^{21}$

In ways both large and small, Dean Kadish has shown us how to be good theorists. He has taught us face-to-face by encouraging, nudging, and disagreeing, always pushing us to sharpen the discussion of a particular point. He has taught us by the example he has set, an example of intense fascination with the intellectual puzzles of the field. Most important, he has taught us by his commitment, at so many points in his career, to bringing theory to bear with force and immediacy on the everyday terrain where our theories affect the lives and prospects of vast numbers of our fellow citizens.

16. See Sanford H. Kadish, Methodology and Criteria in Due Process Adjudication-A Survey and Criticism, 66 YALE L.J. 319 (1957).

17. See Fred R. Shapiro, The Most-Cited Articles from the Yale Law Journal, 100 YALE L.J. 1449 (1991).

18. See Sanford H. Kadish, Legal Norm and Discretion in the Police and Sentencing Processes, 75 HARV. L. REv. 904 (1962).

19. See Mortimer R. Kadish \& Sanford H. Kadish, On Justified Rule Departures by Officials, 59 Calif. L. Rev. 905 (1971).

20. See Mortimer Kadish \& SANFORd KADISH, DisCretion to Disobey (1973).

21. See United States v. Dougherty, 473 F.2d 1113, 1132 (D.C. Cir. 1972) (citing M.R. Kadish \& S.H. Kadish, supra note 19, at 914). 